\title{
Behavioural Tendencies of LIS Undergraduates towards Computer Based Examinations (CBE) in Nigeria
}

\author{
Ogagaoghene Uzezi Idhalama (CLN) \\ Department of Library and Information Science \\ Ambrose Alli University, Ekpoma-Edo State, Nigeria \\ e-mail: idhalamao@gmail.com / idha.lama@aauekpoma.edu.ng \\ Obiora Kingsley Udem \\ Department of Library and Information Science \\ Nnamdi Azikiwe University Awka, Nigeria \\ e-mail:ok.udem@unizik.edu.ng \\ Angela Ishioma Dime \\ Department of Library and Information Science \\ Niger Delta University, Wilberforce Island, Nigeria \\ e-mail:angelisticbabeg@gmail.com
}

\begin{abstract}
This study investigated behavioural tendencies of Library and Information Science undergraduates towards CBE in Nigeria. Five objectives and two hypotheses were formulated to guide the study. Descriptive survey research design was adopted using the online survey monkey app to collect data/responses from library and information science (LIS) undergraduates. The population of the study comprised all LIS students in Nnamdi Azikiwe University, Ambrose Alli University and Benson Idahosa University. The sampling technique used for the study was total enumeration sampling technique (169) as the whole responses were used for the analysis using charts and tables for easy appreciation and comprehension. Also two null hypotheses were tested at alpha level 0.05 using Analysis of Variance (ANOVA). It was found out that: Most of the respondents studied prefer Computer based examination to Paper based examination and both concurrently, respondents have positive perception towards Computer Based Examinations (CBE), majority of the students in the three universities have quite a positive attitude towards Computer Based Examinations (CBE), majority of the respondents agreed to the problems facing the full adoption and use of $C B E$ in their institutions, there is a statistically significant difference between the means of the different rates of perception of the undergraduates towards CBE in federal, state and private universities variable and others. Obviously, students of this generation wish to continue learning using modern technological devices. To this end, government and school administrators should endeavour to encourage the use of $C B E / C B T$ and other ICT facilities in order to fast track teaching and learning among students. This will not only help students but also help teachers in easily realizing objectives.
\end{abstract}

Keywords: CBE, CBT, ICT competencies, Computer based examination, behavioural tendencies

\section{Introduction}

Technology has brought countless benefits and succour to the academic sector and other sectors at large. Whether we like it or otherwise, technology has come to stay in developing 
countries like Nigeria. The good side of technology obviously outweigh the ugly side of it; this is the reason why students, pupils, teachers, digital kids now demand it for effective learning and teaching. Learning through technology has arguably become a lifestyle as students are very familiar with a number of technologies outside the classroom. It will therefore make schools become smart if various technologies are fully introduced in the studying/learning terrain. Sutherland (2020) therefore noted that the right technologies is what the $21^{\text {st }}$ century schools now need as present learning environment has now become dynamic to the point that the learners we have today are far different from the learners our educational system was initially developed for. The author therefore suggested that there is need for classrooms to be remodelled to accommodate modern and digital learners we have today. A very appropriate example of such technology is a type of exam written using computers and not the normal Paper Based Examinations (PBE). This, which is often referred to as Computer Based Examination (CBE) is what is currently becoming in vogue in most developing countries including Nigeria.

A Computer Based Examination (CBE) otherwise known as computer based tests are those examinations that are written or conducted via the computer (electronic) and not pencil and paper format. In this form of examination, students are practically made to sit in front of computer monitors, questions displayed on the screen and answers submitted by candidates or students through the use of mouse and keyboard. According to Burnett (2019), a computer based examination (CBE) is often referred to as a digital assessment or an electronic evaluation which encourages computers (especially laptops) and digital form of examinations and not necessarily paper based.

In another sense, CBT which represents computer based test/examination is used to mean a digital form of an assessment carried out through the means of laptops and other forms of computers. This type of exam which is now a very common form of exam in Africa is basically carried out at a venue completely equipped with all necessary electronic devices and gadgets which assist students that will be participating in the test or exam as the case may be. On his part, Negi (2020) remarked that CBE which means an online assessment is now what is in vogue as far as all Indian entrance examinations are concerned. This he said encourages the smoother evaluation of candidates and also ensures accuracy. To Fagbola, Adigun and Oke (2013), the conventional way of writing exams which is the pencil and paper may be gradually hitting the rock because of the challenges usually associated with it. Some of the problems they highlighted are the cost of printing papers, delay in the releases of results, examination malpractice, lack of flexible timing, lack of fairness of examiners and others. It is quite obvious therefore that the paper and pencil test (PPT) is gradually but surely becoming outdated as the CBT is fast taking over.....

Observations show that most universities in Nigeria have their CBE centres domiciled in their libraries and this therefore makes this study quite interesting as the respondents/population of this study will be the students of library and information science in three leading universities in Nigeria (a private university, a state government university and a federal government university). The history of CBT/CBE in Nigeria can be traced to the era of post JAMB examination. To this end, Alabi, Issa and Oyekunle (2012) stated that the Joint Admission and Matriculation Board (JAMB) which was founded in Nigeria in 1978 and amended in 1989 is Nigeria's official body charged with the responsibility of conducting pre University examinations. In 2005 the university system in Nigeria launched what they term post JAMB screening examination as a means of authenticating or validating scores obtained from JAMB. In response to some challenges faced in assessing candidates through the paper and 
pencil test, the university of Ilorin through her Senate became one of the first universities in Nigeria to commence the Computer Based Test for applicants in the year 2008 (Alabi, Issa, and Oyekunle, 2012). Similarly, Nnamdi Azikiwe University which is a federal university in Nigeria was said to have started computer based examination in 2015 as reported by Nnamdi Azikiwe University (nd). It is obvious today that our lives have changed in many areas as our day to day living is interconnected with technology. We as librarians or librarians in making cannot therefore afford to lag behind by way of negligence or ignorance. Also according to Peter (2019) while quoting the Vice-Chancellor (VC) of Ambrose Alli University noted that computer based examination was introduced into the university immediately he took over the mantle of leadership in 2016. According to the author, Professor Ignatius Onimawo who is the current VC of Ambrose Alli University affirmed that the step was taken in order to check examination malpractice and sexual advances from some dubious university teachers. The VC was said to note that though there was initial resistance, lecturers presently see the step as that which in the right direction as they no longer mark/assess too many scripts. Similarly, the Benson Idahosa University which is a Christian and private university in Nigeria was said to have been founded in 2002 and commenced computer based examinations in 2017.

Technology has taken the central stage in all human activities while some people find it interesting, others see it as a distraction and obstruction. Librarians and librarians in the making are also caught in the web of adaptation and adjustment to the daily itinerary with particular reference to electronic gadgets and equipment. As would-be librarians, it is imperative to be conversant with digital/electronic gadgets, this is hinged on the fact that library and information professionals are said to interact with these gadgets on a daily basis at work and also in the home front. This study on the behavioural tendencies of undergraduates becomes relevant as it is aimed to investigate students' perception and attitude towards CBE/CBT. It will further unveil the benefits and challenges accrued from the undergraduates' point of view.

\section{Objectives of the Study}

A major objective adopted for this study is to ascertain the behavioural tendencies of library and information undergraduates towards Computer Based Examinations (CBE) in Nigeria. There are other specific objectives which are listed as follows:

1. To determine the preferred type of examination between CBE and paper based examination by LIS students in Nigeria.

2. To determine the perception of Library and Information Science (LIS) undergraduates towards Computer Based Examinations (CBE) in Nigeria.

3. To ascertain the attitude of LIS undergraduates towards CBE in Nigeria.

4. To find out the benefits of Computer Based Examination to LIS undergraduates in Nigeria.

5. To investigate the challenges posed by CBE to LIS undergraduates in Nigeria

\section{Hypotheses}

1. There is no significant difference in the mean rating of the perception of LIS undergraduates towards CBE in federal, state and private universities in Nigeria.

2. There is no significant difference in the mean rating of the attitude of LIS undergraduates towards $\mathrm{CBE}$ in federal, state and private universities in Nigeria. 


\section{Literature review}

\section{Preferred Examination System between CBE and Paper Based Examination}

It is a general notion that examinations are conducted in order to assess or determine the academic performance of students. Today, there are three major examination methods being used in schools especially the tertiary institutions in Nigeria. There is that of paper based examination (PBE), computer based examination (CBE) and both of them, often referred to as the hybrid system. Since the advent of the computer based assessment method, a number of stakeholders had shown their support for the technology, while others still believe that the system could be disregarded or discarded. The library and information science undergraduates as junior stakeholders are also in the position to decide the type of system they prefer. Whichever option they may want to be introduced in their schools, that may not stop the growing trend in information and communication technology in both developing and developed countries of the world. This, Jamil, Tariq and Shami (2012) supported when they hinted that both computers and other allied technologies are capable of providing very powerful platforms for learning and teaching from primary through tertiary institutions.

\section{Perception of Computer Based Examination by LIS Students in Nigeria}

In the three Universities to be studied which are Nnamdi Azikiwe University, Ambrose Alli University and Benson Idahosa University, preliminary investigation indicates that some students are still grabbling with the relatively new technology introduced in their institutions while some believe that it is a very welcome development to adopt, other students believe that the CBE technology has its own deficiencies that need urgent attention. In the study that was carried out by Jennifer-Hooper (2020), the students studied disclosed that they lacked self confidence in answering questions while using the CBE compared to paper based system. This they said is sequel to the fact that they could not read the questions enough as it took them less time in writing CBE compared to PBE. In the computer based examination, some students are of the view that the technology is cumbersome and complicated as some functions that are common with the Paper Based Examination (PBE) had been eliminated. Some of these functions are, writing notes, striking of answers, highlighting, circling and others.

Some students will no doubt see the online testing as a flexible and efficient method as it makes it possible for students to immediately see their scores after hitting the submit button.... However, there are reservations in some quarters that the immediate feedback which students are exposed to through the computer based examination has a way of psychologically affecting them either positively or negatively. What this implies is that some students may feel devastated when the feedback for a just concluded examination is not encouraging enough. This of course may affect such students' performance in other subsequent exams to be written. There is a popular belief that we now live in the ICT era where there are smart schools. To this end, students believe that it is only normal to blend with this society we found ourselves by adopting all the ICT attachments as it were. This will therefore put Nigerian students at par with their counterparts in other developed countries. Obikeze, et al (2019) on their part noted that students feel that the CBE is modelled in a way that it is self navigating where any students finds it easy to navigate through and successfully submitting questions at the end of the examination. Some of the easy navigation can be seen as ability to log in easily, lively site colour, appropriate interface design and others. The time being displayed on the screen is a good spur that encourages students to hurry and ensure that 
all questions are attempted before the expiration of the allotted time. This may also have a negative impact as seeing the remaining time left could make them apprehensive and disorganised. To some students according to Knaack (2010), they naturally do better and feel more comfortable when allowed to use paper based learning instead of computer based. This set of students may belong to the category of technophobes who feel uncomfortable with the introduction of new a technology. Students who happily accept new technologies in learning are certainly expected to be more dynamic and smarter than those who shy away.

\section{Attitude of LIS Undergraduates towards CBE}

Attitude here is used to mean acceptance or behaviour of student regarding computer based test. There are a number of library and information science students that may wish to accept the CBE technology or reject it. It must be noted therefore that attitudes are developed through experience and these experiences can be changed through internal and externally related factors. Library and information Science (LIS) students' attitude could be either positive or negative depending on their understanding or feeling towards that particular thing or concept. Adeyinka and Bashorun (2012) while discussing the attitude of students toward CBE hinted that quite a number of students, just like LIS students develop anxiety while writing examinations online. The authors used the concept of anxiety to mean feeling of apprehension, fear or worry with uncertain results. It has been observed that some LIS students who do not or have limited knowledge of ICT face computer based examination with fear or nervousness. It is an obvious fact that the extent of student's literacy in ICT will determine his commitment and motivation to wanting to write exams through computer based platforms. Many students find computer based examination system comfortable because of the background system they earlier possessed before entering the university.

Wood (2020) stated that there are a number of attitudes exhibited by LIS students when it comes to writing examinations via the computer based platform. The author noted that some students may feel bored, some may develop anxiety, others may be irritated and some may want all their exams to be conducted online and many other attitudes. Wood therefore added that it depends largely on the level of ICT competence of the students in order to develop positive or negative attitude. In the study of Ali and Bhat (2018), it was discovered that their respondents from Arts and the sciences showed positive attitude towards computer based examinations. This finding was attributed to the fact that the students had access to computers at their various homes. In their similar study, Yang and Kwok (2016) in Siragusa and Dixon studied the attitude of students towards their involvement in CBE. The tabulated quantitative data showed that students agreed that interacting with CBE was helpful, easy and useful to them, on the other hand, the qualitative data therefore showed that there were some students that felt some level of discomfort and anxiety in the use of computers for writing their examinations. To Wu (2012), who studied issues, relating to CBE by university students discovered that both qualitative and quantitative respondents had a deep understanding of usefulness and ease of use of CBE. There is no doubt that both factors influence technology user acceptance and by extension behaviour. From the literature review on the attitude of LIS undergraduates towards $\mathrm{CBE}$, it is therefore clear that there are two opposite sides when we talk about attitude. It could be positive or negative. At this point, the researchers remain in suspense as par what the LIS students' attitude would be at the end of this research paper.

\section{Benefits of Computer Based Examination (CBE) to LIS Students}

The computer-based examination which is gradually becoming a popular and common platform for writing exams in Nigerian universities is said to have numerous benefits; though 
some authorities believe that paper-pencil examination is preferable. According to Burns (2018), the advantages of computer based examination outweigh the disadvantages as the benefits can never be underestimated. She noted that some of the benefits are dynamic and individualised assessments, immediate grading, feedback, open-ended assessments, uncover student-thinking, engaging, greater amount of text items and others.

It must be noted that the CBE may no doubt, become the standard platform for writing all examinations, this is based on the fact that there are currently some new packages capable of assessing students with modified essay questions. This is contrary to beliefs by some people that computer based assessment can only be down with objective questions. Among the many advantages of the $\mathrm{CBE}$ are time management (allotted time displays on the screen), seamless web connection, absence of partiality and many more. An online assessment which is traditionally conducted digitally is meant to evaluate knowledge of students using a particular curriculum. Malguri (2020) observed that the CBE system is quite better than the paper based examination when he itemized some of the benefits to be, advancing technologically, minimizing cost of labour, effective time management, limiting overheads, better privacy and security and others.

Apart from time management, some stakeholders believe that the CBE helps to curb examination malpractice and corruption of some lecturers who take bribe from their students. This is hinged on the backdrop that students see their results almost immediately after submitting their question via the computer. There is also the argument on cost as the CBE system is said to save cost of producing papers and other necessary items in the paper based exam system. Quite a number of university Vice Chancellors in Nigeria believe that CBE system is the way forward, this is the rationale why the universities under study (Nnamdi Azikiwe University, Ambrose Alli University and Benson Idahosa University) have all keyed into the system. It is also believed that the computer based examinations are more efficient, more flexible, can be taken any time of the year without much preparation, individual testing environment, simple computer interface and faster scoring. To Swise (2020), there are two major advantages of the CBE, she noted that $\mathrm{CBE}$ has the tendency of saving budget/cost and also the capability of minimising cheating during examinations.

Also, to Osuagwu et al (2018), the benefits of CBE are numerous which they listed as follows:

- Greater flexibility

- Immediate exam score (feedback) is generated

- Lower long-term cost

- Creation of digital records of students

- Impartial assessment (no victimisation)

- Randomization of question reduces cheating

- Improved system reliability

\section{Challenges of Computer Based Examinations as Observed by LIS Students}

Preliminary investigation indicates that a reasonable number of LIS students are not satisfied with the CBE system as they highlighted quite a number of issues. Some noted that erratic power supply is a major challenge as often times computers trip off just few minutes into the examination. A few students are not particularly happy with the system owing to the fact that they are not ICT savvy which makes them find the CBE system not too interesting. There are other challenges of $\mathrm{CBE}$ which can be traced to poor or low internet connectivity and also 
inadequate or few computers for students to utilize. Okoye (2018) who remarked that CBE has come to stay in Nigeria's assessment of students noted that LIS students still face quite a number of challenges which include but not limited to

- inadequate provision of computers

- Poor internet connectivity

- Inadequate technical staff

- Lack of ICT knowledge on the part of students

- Epileptic power supply

- Period of time allotted inadequate

- Seating accommodation provided not enough

- Unfriendly attitude of invigilators

- CBE promotes tension

Notwithstanding, one can only encourage Vice Chancellors and other university administrators to perpetually propagate the gospel or the act of embracing new trends in technology even as they try harder to reduce or eradicate challenges faced by students. Osuagwu et al (2018), averred the CBE system has long taken over paper based system, but they were quick to acknowledge that few challenges still exist which are: lack of technological gadgets, students' inadequate skills in ICT, problem of power supply and problem of acceptability on the part of lecturers and students. The authors by extension suggested that there was need for government to intervene in curbing the challenges. They suggested also that a compulsory course on computer training should be introduced at the primary school level.

\section{Methodology}

In this study, the descriptive survey research design was adopted using the online survey monkey app to collect data/responses from library and information science (LIS) undergraduates. The population of the study comprised all LIS students in Nnamdi Azikiwe University (NAU/UNIZIK), Ambrose Alli University (AAU) and Benson Idahosa University (BIU). The sampling technique used for the study was total enumeration sampling technique (169) as the whole responses was used for the analysis using charts and tables for easy appreciation and comprehension. Also two null hypotheses were tested at alpha level 0.05 using Analysis of Variance (ANOVA).

\section{Presentation and Analysis of Data}

Table 1: Gender

\begin{tabular}{|c|c|c|c|c|c|}
\hline \multicolumn{2}{|c|}{ Gender } & Frequency & Percent & Valid Percent & Cumulative Percent \\
\hline Valid & Male & 67 & 39.6 & 39.6 & 39.6 \\
\cline { 2 - 6 } & Female & 102 & 60.4 & 60.4 & 100.0 \\
\cline { 2 - 6 } & Total & 169 & 100.0 & 100.0 & \\
\hline
\end{tabular}

The table 1 shows clearly that there were more female (102) who responded to the research questions than their male counterparts (67)

Table 2: University

\begin{tabular}{|c|c|c|c|c|c|}
\hline \multicolumn{2}{|c|}{ University } & Frequency & Percent & Valid Percent & Cumulative Percent \\
\hline \multirow{4}{*}{ Valid } & NAU/UNIZIK & 69 & 40.8 & 40.8 & 40.8 \\
\cline { 2 - 6 } & AAU & 56 & 33.1 & 33.1 & 74.0 \\
\cline { 2 - 6 } & BIU & 44 & 26.0 & 26.0 & 100.0 \\
\cline { 2 - 6 } & Total & 169 & 100.0 & 100.0 & \\
\hline
\end{tabular}


From table 2, it can be seen that majority of respondents are from Nnamdi Azikiwe University otherwise called NAU/UNIZIK (69), followed by Ambrose Alli University also known as AAU(56)and Benson Idahosa University known as BIU(44).

Objective 1: Type of Examination preferred by LIS Undergraduates

Table 3: LIS Undergraduates Responses on preferred Type of Examination

\begin{tabular}{|c|c|c|c|c|c|}
\hline \multicolumn{2}{|c|}{} & Frequency & Percent & Valid Percent & Cumulative Percent \\
\hline \multirow{4}{*}{ Valid } & PBE & 32 & 18.9 & 18.9 & 18.9 \\
\cline { 2 - 6 } & CBE & 81 & 47.9 & 47.9 & 66.9 \\
\cline { 2 - 6 } & both & 56 & 33.1 & 33.1 & 100.0 \\
\cline { 2 - 6 } & Total & 169 & 100.0 & 100.0 & \\
\hline
\end{tabular}

From the result as indicated in table 3 , most of the respondents prefer Computer based examination (CBE) (81), followed by those that prefer both CBE and paper based examination (56) and those that prefer only paper based examinations (32). This finding is in line with Franklyn (2020) when he noted that students are now exposed to different technologies and use them more than the last generations. This has no doubt moved to the classroom where all students wish to access and use available modern devices for learning, using these technologies for tests and examinations is therefore the next step.

Objective 2: To determine the perception of Library and Information Science (LIS) undergraduates towards Computer Based Examinations (CBE) in Nigeria.

Table 4: Undergraduate Responses on their perception towards Computer Based Examinations (CBE)

\begin{tabular}{|l|c|c|c|c|c|}
\hline Perception & $\mathrm{N}$ & Min & Max & Mean & Std. Deviation \\
\hline I believe that CBE is technical & 169 & 1 & 2 & 1.16 & .367 \\
\hline $\begin{array}{l}\text { I think that CBE is the best system of exam } \\
\text { CBE_never_a test_knwldge }\end{array}$ & 169 & 1 & 2 & 1.49 & .501 \\
\hline I know that CBE is not_flexible_enough & 169 & 1 & 2 & 1.16 & .367 \\
\hline I know that CBE_is very_efficient & 169 & 1 & 2 & 1.38 & .488 \\
\hline I have positive_thoughts abt_CBE sys & 169 & 1 & 2 & 1.43 & .497 \\
\hline I think that CBE system should be sustained & 169 & 1 & 2 & 1.33 & .470 \\
\hline CBE_should_be_stopped & 169 & 1 & 2 & 1.09 & .294 \\
\hline $\begin{array}{l}\text { I know that CBE is simple for me to write } \\
\text { exam }\end{array}$ & 169 & 1 & 2 & 1.40 & .492 \\
\hline I feel comfortable_with_CBE & 169 & 1 & 2 & 1.44 & .498 \\
\hline Other & 169 & 1 & 2 & 1.09 & .285 \\
\hline Valid N (listwise) & 169 & & & & \\
\hline
\end{tabular}

From the presentation in table 4 , it is indicated that most of the respondents believe that CBE is the best system of exam (1.49), followed by those that feel comfortable with CBE (1.44), those that have positive thought about CBE (1.43) and others. This finding therefore shows that they have positive perception towards Computer Based Examinations (CBE). Similar to this finding is that of Anene (2016) when the students she studied perceived that CBE is a concrete and reliable platform for examining students which they said is more preferable than paper based examination. 
Objective 3: To ascertain the attitude of LIS undergraduates towards CBE in Nigeria.

Table 5: LIS Undergraduates Responses on their attitude towards CBE

\begin{tabular}{|c|c|c|c|c|c|}
\hline Attitude & $\mathrm{N}$ & Min & Max & Mean & Std. Dev \\
\hline I develop anxiety writing CBEs & 169 & 1 & 2 & 1.30 & .458 \\
\hline $\begin{array}{l}\text { I am always bored when it comes to } \\
\text { CBE }\end{array}$ & 168 & 1 & 2 & 1.11 & .310 \\
\hline $\begin{array}{l}\text { It is very interesting writing al exams } \\
\text { on CBE platform }\end{array}$ & 169 & 1 & 2 & 1.54 & .500 \\
\hline I get irritated writing CBEs & 169 & 1 & 2 & 1.09 & .294 \\
\hline $\mathrm{CBE}$ is the best thing I enjoy & 169 & 1 & 2 & 1.43 & .497 \\
\hline $\begin{array}{l}\text { I want to write all my exams on CBE } \\
\text { platform }\end{array}$ & 169 & 1 & 2 & 1.31 & .465 \\
\hline I am an expert when it comes to CBEs & 169 & 1 & 2 & 1.21 & .411 \\
\hline Others & 169 & 1 & 2 & 1.08 & .276 \\
\hline Valid N (listwise) & 168 & & & & \\
\hline
\end{tabular}

In table 5, most respondents indicated that they find it interesting writing exam on CBE platform (1.54), followed by those that responded that CBE is the best thing they enjoy (1.43)and followed by those that want to write all their exams using computers (1.31). This there indicates that the students in the three universities have quite a positive attitude towards Computer Based Examinations (CBE). In the area of attitude this findings is similar to that of Dammas (2016) when the author found that students enjoyed taking their examinations through computer based platform thereby making it a positive attitude towards CBE.

Objective 4: To find out the benefits of Computer Based Examination to LIS undergraduates in Nigeria

Table 6: LIS undergraduates Responses on the benefits of Computer Based Examination

\begin{tabular}{|l|c|c|c|c|c|}
\hline Benefits & $\mathrm{N}$ & Min & Max & Mean & Std. Dev \\
\hline The CBE system is flexible & 169 & 1 & 2 & 1.45 & 0.499 \\
\hline There is impartial_assessment & 169 & 1 & 22 & 1.43 & 1.657 \\
\hline CBE_discourages_corruption on the part of lecturers & 169 & 1 & 2 & 1.54 & 0.5 \\
\hline There is fraud_in CBE & 169 & 1 & 2 & 1.12 & 0.324 \\
\hline CBE is_not_reliable & 169 & 1 & 2 & 1.16 & 0.367 \\
\hline There is effective_time_mgt. & 169 & 1 & 2 & 1.44 & 0.498 \\
\hline Immediate_grading/scoring & 169 & 1 & 2 & 1.63 & 0.483 \\
\hline CBE_system is useless & 169 & 1 & 2 & 1.01 & 0.108 \\
\hline others_ & 169 & 1 & 2 & 1.01 & 0.077 \\
\hline Valid N (listwise) & 169 & & & & \\
\hline
\end{tabular}

In table 6, respondents agreed that numerous benefits accrued when CBE is introduced into a learning system, most of them noted that a good example of such benefits is immediate grading (1.63), followed by others that noted that $\mathrm{CBE}$ discourages corruption (1.54), followed by those that said CBE system is flexible (1.45) and those that agreed that CBE encourages effective time management (1.44). The findings correspond with the views of Sareen (2018) when the author noted that computer based tests have come to stay in recent times, as popular entrance examinations are being conducted via computers. The author listed 
some of the benefits to be immediate results, time management, saving cost, students becoming more technologically savvy and other more.

Objective 5: To investigate the challenges posed by CBE to LIS undergraduates in Nigeria.

Table 7: LIS undergraduates Responses on the challenges posed by CBE

\begin{tabular}{|l|c|c|c|c|c|}
\hline Challenges & $\mathrm{N}$ & Min & Max & Mean & Std. Dev \\
\hline Poor internet connection & 169 & 1 & 2 & 1.72 & .452 \\
\hline Inadequate technical staff & 169 & 1 & 2 & 1.38 & .487 \\
\hline Epileptic power supply & 169 & 1 & 2 & 1.39 & .489 \\
\hline Unfriendly attitude of invigilators & 169 & 1 & 2 & 1.36 & .482 \\
\hline Poor ICT knowledge of students & 169 & 1 & 2 & 1.47 & .500 \\
\hline CBE promotes tension & 169 & 1 & 2 & 1.28 & .452 \\
\hline Allotted time always inadequate & 169 & 1 & 2 & 1.54 & .500 \\
\hline Inadequate computer system & 169 & 1 & 2 & 1.43 & .496 \\
\hline Others & 169 & 1 & 2 & 1.02 & .132 \\
\hline Valid N (listwise) & 169 & & & & \\
\hline
\end{tabular}

From the table 7, it is clear that majority of the respondents agreed to the problems facing the full adoption and use of CBE in their institutions. Most of the students agreed that a major problem they face is poor internet connection (1.72). This is followed by those that said allotted time is always inadequate (1.54), followed by those that noted that some students have poor knowledge of ICT (1.47, followed by students who indicated that there are inadequate computer systems (1.43) and others. This finding is in sync with that of Okoye (2019) when the author discovered that in Nigeria that there is a high extent of challenges faced by students in a bid to utilize the computers in writing their exams. Some of the challenges noted are epileptic power supply, inadequate computers, harsh attitude of invigilators and others.

\section{Hypotheses}

There is no significant difference in the mean rating of the perception of LIS undergraduates towards CBE in federal, state and private universities in Nigeria.

\section{ANOVA}

Table 8: ANOVA analysis on difference in the mean rating of the perception of LIS undergraduates towards CBE in federal, state and private universities

\begin{tabular}{|c|c|c|c|c|c|}
\hline & Sum of Squares & Df & Mean Square & F & Sig. \\
\hline Between Groups & 23.698 & 2 & 11.849 & 3.333 & .038 \\
\hline Within Groups & 590.231 & 166 & 3.556 & & \\
\hline Total & 613.929 & 168 & & & \\
\hline
\end{tabular}

From the first hypothesis, significant result, the value of $\mathrm{F}$ is 3.3 , which reaches significance with a $p$-value of .038 (which is less than the .05 alpha level). This means there is a statistically significant difference between the means of the different rates of perception of the undergraduates towards $\mathrm{CBE}$ in federal, state and private universities variable, it was found that since the exact significance level (.038) provided in SPSS output, is lesser than 
alpha (.05) the results is statistically significant, thus the null hypothesis is rejected and therefore this shows that there is a significant difference in the mean rating of the perception of LIS undergraduates towards CBE in federal, state and private universities in Nigeria. The result of both the ANOVA test thus shows that there was a statistically significant difference between groups as demonstrated by one-way $\operatorname{ANOVA}(F(3,169)=3.3, p=.038)$.

There is no significant difference in the mean rating of the attitude of LIS undergraduates towards $\mathrm{CBE}$ in federal, state and private universities in Nigeria.

\section{ANOVA}

Table 9: ANOVA analysis on difference in the mean rating of the attitude of LIS undergraduates towards CBE in federal, state and private universities

\begin{tabular}{|c|c|c|c|c|c|}
\hline & Sum of Squares & Df & Mean Square & F & Sig. \\
\hline Between Groups & .009 & 2 & .004 & .722 .487 \\
\hline Within Groups & .986 & 166 & .006 & & \\
\hline Total & .994 & 168 & & & \\
\hline
\end{tabular}

From the second hypothesis, significant result, the value of $F$ is 0.7 , which reaches significance with a $p$-value of .48 (which is greater than the .05 alpha level). This means there is no statistically significant difference between the means of the different rates of attitude of LIS undergraduates towards CBE in federal, state and private universities in Nigeria, it was found that since the exact significance level (.48) provided in SPSS output, is greater than alpha (.05) the results is statistically significant, thus the null hypothesis is accepted and therefore this shows that there is no significant difference in the mean rating of the attitude of LIS undergraduates towards CBE in federal, state and private universities in Nigeria. The result of both the ANOVA test thus shows that there was no statistically significant difference between groups as demonstrated by one-way $\operatorname{ANOVA}(F(3,169)=0.7, p=.48)$

\section{Summary of Findings}

- Most of the respondents studied prefer Computer based examination to Paper based examination and both concurrently.

- Finding shows that respondents have positive perception towards Computer Based Examinations (CBE).

- Finding indicates that majority of the students in the three universities have quite a positive attitude towards Computer Based Examinations (CBE).

- Most respondents agreed that numerous benefits accrued when CBE is introduced into a learning system.

- Majority of the respondents agreed to the problems facing the full adoption and use of $\mathrm{CBE}$ in their institutions.

- There is a statistically significant difference between the means of the different rates of perception of the undergraduates towards $\mathrm{CBE}$ in federal, state and private universities variable. Null hypothesis rejected.

- There is no statistically significant difference between the means of the different rates of attitude of LIS undergraduates towards CBE in federal, state and private universities in Nigeria. Null hypothesis accepted. 


\section{Conclusion}

Going by the findings of this study, it has shown that computer based examinations are the best and have come to stay. Obviously, students of this generation wish to continue learning using modern technological devices. To this end, government and school administrators should endeavour to encourage the use of CBE/CBT and other ICT facilities in order to fast track teaching and learning among students. This will not only help students but also help teachers in easily realizing objectives.

\section{References}

1. Adeyinka, J., \& Bashorun M. T. (2012). Attitude of Undergraduate Students Towards Computer Based Test (CBT). International Journal of Information and Communication Technology Education, 8(2), 32- 45

2. Alabi, A.T., Issa, A. O. \& Oyekunle, R. A. (2012). The Use of Computer Based Testing Method for the Conduct of Examination of the University of Ilorin. International Journal of Learning \& Development, 2(3) 1-14.

3. Anene, E. I. (2016). Assessment of students' perception of Joint Admission and Matriculation Board computer based examination in Nnamdi Azikiwe University Awka, Anambra State Nigeria. Retrieved from http://www.jatit.org

4. Burnet T, (2019). What is Computer-Based Test? Retrieved from: https://www.quora.com

5. Burns, M. (2018). 15 Benefits of Computer-Based Testing. Retrieved from https://www.elearningindustry.com.

6. Dammas, A. H. (2016). Investigates students' attitude towards CBT at chemistry course. Archives of business research, 4(6), 1-14.

7. Fagbola, T.M., Adigun, A.A. and Oke, A.O. (2013). Computer-Based Test (CBT) System for University Academic Enterprise Examination. International Journal of Scientific \& Technological Research, 2(8) 336-342.

8. Franklyn, D. (2020). The new generation of students in this era. Retrieved from: https://www.econ.hty.lim.com

9. Jamil, M. Tariq, R. H. \& Shami, P. A. (2012). Computer Based Vs Paper-Based Examinations. Perception of University Teachers. The Turkish Online Journal of Educational Technology, 11(4) 1-11.

10. Jennifer-Hooper, M. N. (2020). Undergraduate Nursing Students' Perception of Computer Based Testing. Canadian Journal of Nursing Informatics, 15(1). Retrieved from https://ejinet/jouranl/?p=6828

11. Knaack, M. (2010). Computer Based Instruction and its Effects on 21st Century Learners. Retrieved from https://digital.commons.odu.edu/ots_masters_projects

12. Malguri, A. (2020). The Advantages and Disadvantages of an Online Examination System. Retrieved from https://www.blog.wettl.com

13. Negi, A. (2020). India Premier Infrastructure and Test Delivery. Retrieved from https://www.vensysco.com

14. Nnamdi Azikiwe University (n.d.). School of General Studies. Retrieved from https://unizik.edu.ng.

15. Obikeze, N. et al (2019). Perception of Lecturers on the Use of Computer Based Test (CBT) in Nigerian Public Universities. Online Journal of Arts Management and Social Science (OJAMSS) 4(1) 223-246. 
16. Okoye, F.O. (2018). Challenges of 2018 Computer-Based Test (CBT) JAMB Examination for Senior Secondary School Students Academic Performance in Anambra State, Nigeria. European Journal of Education Studies,6(3), 1-12.

17. Osuagwu, C.I., Akamere, F. Joseph O.C. \& Agunenye, J. (2018). Advanced Management in the Examination System: The Computer Based Test and its Challenges. International Advanced Journal of Teaching and Learning, 4(1)40-47.

18. Peter, A. (2019). Computer-Based Examination Have Reduced Workload. Retrieved from https://www.punchng.com

19. Sareen, S. (2018). Advantages of taking a computer based test (CBT) exam: A detailed analysis. Retrieved from: https://www.colledgeddekho.com

20. Sutherland, C. (2020). 7 Reasons Why Students Need Technology in the Classroom. Retrieved from https://www.explorance.com

21. Wood, C.O. (2020). The Basics of Attitudinal Shifting Towards Information Technology and Science Education. International Research: Journal of Library and Information Science, 8(1), 2018. 